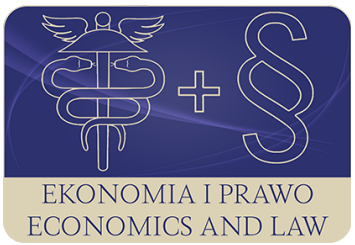

EKONOMIA I PRAWO. ECONOMICS AND LAW

Volume 20, Issue 2, June 2021

p-ISSN 1898-2255, e-ISSN 2392-1625

www.economicsandlaw.pl

ORIGINAL ARTICLE

received 07.10.2020; revised 20.06.2021; accepted 30.06.2021

Citation: Revko, A. (2021). Determinant of educational infrastructure development in conditions of regional economy transformation and digitalization. Ekonomia i Prawo. Economics and Law, 20(2), 413-424. https://doi.org/10.12775/EiP.2021.025.

\title{
Determinant of educational infrastructure development in conditions of regional economy transformation and digitalization
}

\begin{abstract}
ALONA REVKO
Chernihiv Polytechnic National University, Faculty of Social Work, Health Improvement and Rehabilitation, Department of Social Work, Kozatska street 1a, Chernihiv, 14000, Ukraine

๑alohaha19@gmail.com

(iD) orcid.org/0000-0001-7888-3657
\end{abstract}

\begin{abstract}
Motivation: In the context of sustainable development, it is objectively conditioned to base the social infrastructure development on the transformations and digitalization of the regional economic space. The transformation of the potential of social infrastructure involves changing not only the quantitative parameters of its components, but also transforming the objects of the infrastructure complex of the region, restructuring the connections between them and moving to a qualitatively new level of development. The determinant of social infrastructure that provides quality human development is education.

High-quality educational infrastructure provides comprehensive human development through the formation of a complex of services necessary for the qualitative development of human potential.

Aim: The purpose of the research is to analyse the structural and dynamic features of the educational component of social infrastructure at the meso level in Ukraine and Poland, to work out practical recommendations for its transformation and digitalization. Results: An author's methodology for assessing the educational infrastructure development is developed. The methodology includes, in particular, the calculation of the synthetic index for the educational infrastructure development using the method of linear ordering by Julian Perkal. The negative trend of decreasing in the number of Ukrainian educational institutions between 2010 and 2020 is detected. It is established that the dynamics of the number of students in vocational schools and higher education institutions
\end{abstract}


in Ukraine reflects, first, the demographic trends that have taken place and are taking place in the country, as well as society's attitude to vocational and higher education. In addition, the rating of Ukrainian and Polish regions according to the level of the educational infrastructure development is created.

Keywords: educational infrastructure; human development; regional economy; social infrastructure; digitalization; social capital

JEL: I20; O15; R10; Y91

\section{Introduction}

Educational infrastructure provides comprehensive human development through the formation of a set of services necessary for the quality development of human potential. It creates products and provides services that have their own consumer value. Moreover, the results of the educational subsystem of social infrastructure affect the efficiency of material production, the creation of conditions and means to improve the technical potential of production, increase the level of general education and skills of workers. It's important to note that the educational infrastructure is the initial vector of regional development and a basis for the formation of a highly developed society. Educational infrastructure consists of pre-school institutions, secondary schools, vocational schoolsand higher education institutions.

The aim of the paper is to: (1) characterize the development level of the educational component of social infrastructure in Ukraine and Poland regions based on grouped statistical indicators, (2) work out of practical recommendations for its transformation and digitalization in the conditions of innovative development of regions.

\section{Social and educational infrastructure: literature review}

Social infrastructure is a multilevel, multifunctional complex with a pronounced territorial character and territorial features. As Wojnowski (2002, p. 134) indicates, social infrastructure is a system of institutions and services that meet human needs in the field of education, culture, security, social security and health care.

Significant impact on the development of social infrastructure, as noted Flora \& Flora (1993, p. 50), provides social capital, which encourages communities to collective action to achieve this goal. Flora (1998, pp. 489-490) emphasises that a community, which has a well-formed social infrastructure, strives for collective action to improve the community has every chance to be entrepreneurial.

In our opinion, the functioning of social infrastructure should correspond to the social policy of the state, which is aimed at improving the quality of life, welfare, formation and reproduction of a healthy, creative and active generation (Revko, 2017, p. 30). 
The consumer of the services of the educational component of social infrastructure is a human. Witkowski \& Starościc (2008, p. 187) argues that human enjoys tangible and intangible benefits for many reasons. One of them is the desire to satisfy one's own needs by increasing the level of knowledge, physical and moral health, general cultural and professional competence. In view of this, social infrastructure, in addition to social activities of the state, is an investment in human, in the development and reproduction of its potential.

According to Kupiec et al. (2004, pp. 32-33), education should be understood as education, training and science as processes of acquiring skills, knowledge and abilities. Moreover, it is the process of passing on from generation to generation the cultural heritage, namely the knowledge, skills and value system of a particular community through a social institution, which is primarily a school. It is important to note that education is the foundation of the modern world, knowledge economy and society as a whole.

Access to quality education is one of the basic rights of everyone, which is reflected in many international documents, as well as in the basic laws of most countries. The realization of the above-mentioned right of citizens to education requires constant development of the educational subsystem of the social infrastructure of the region at all levels, including at the highest level. The level of satisfaction of the needs of the population through the education system depends on the possibility of using educational institutions and the quality of services they provide, as well as on the material base of educational institutions, the number of educational institutions, their equipment and staff skills. Moreover, innovation is the key role of digitalization (development and availability of digital education infrastructure, improving the quality of communication networks, introduction of new data transmission technologies in education, etc.).

It can be claimed that education is the basis of intellectual, spiritual, physical and cultural development of the individual, its successful socialization, economic well-being, the key to the development of a society united by common values and culture, and the state.

\section{Research methods}

The methodological basis for the assessment of educational infrastructure is the application of various methodological approaches to assessing the state and development of the educational sphere of the regions. These are application of the process of optimization of key indicators; use of the method of integration and construction of consolidated indicators (using rating, scores, normalized indicators); application of comparative analysis to compare partial or integrated indicators with different conditions, characteristics, time periods (with the average national standard; with the sample leader; with the world leader; with other regions, etc.).

Based on the study of existing methodological approaches to assessing the level of educational infrastructure development, an author's methodology 
has been developed, the purpose of which is to characterize the level of regional divergence of educational infrastructure based on Perkal's synthetic ratio method, also known in the literature as Z-Scores. Data for this analysis are from Polish and Ukrainian public statistics (State Statistics Service of Ukraine, 2021; Statistic Poland, 2021) and include statistical indicators of educational infrastructure of 16 Polish voivodships and 22 Ukrainian oblasts. The time range for assessing the educational infrastructure covers 2010-2020. The maps were created using the MapInfo Professional software.

The methodological approach of assessing the level of educational infrastructure development in Ukrainian and Polish regions includes the following seven steps such as:

- determination of the list of statistical indicators for the development of educational infrastructure;

- assessment of educational infrastructure based on statistical indicators;

- elimination of variables with low level of differentiation and highly correlated;

- distribution of selected variables into stimulants and destimulants;

- normalization of variables by the standardization method;

- creation synthetic index of educational infrastructure development by Julian Perkal's method;

- ranking of the regions by the level of educational infrastructure development. The basis for comparative research is the choice of variables (statistical indicators) that describe the subject of research. The reliability of the final results of the research and the accuracy of the decisions made on their basis depend on the quality of the variables.

\section{Results}

The first step in the assessing the level of educational infrastructure development in Ukrainian and Polish regions was to identify the variables that describe the object of the research. We have focused on a group of statistical indicators of educational infrastructure development that includes:

- E 1. Number of pre-school institutions (units);

- E 2. Number of children in pre-school institutions per 100 places (person);

- E 3. Number of secondary schools (units);

- E 4. Number of students in secondary schools per 10 thousand of population (person);

- E 5. Number of students in secondary schools per 1 teacher (person);

- E 6. Number of vocational schools (units);

- E 7. Number of students in vocational schools per 10 thousand of population (person);

- E 8. Number of higher education institutions (units);

- E 9. Number of students in higher education institutions per 10 thousand of population (person); 
- E10. Number of students in higher education institutions per 1 teacher (person).

This list of statistical indicators, of course, is not complete, but is considered sufficient to achieve the objectives of this study. It should be noted that each of the 10 identified indicators relates to data from the website of the State Statistics Service of Ukraine (2021) and Statistic Poland (2021).

The dynamics of the number of educational infrastructure institutions in Poland and Ukraine is presented in Table l. There was a negative trend in the number of Ukrainian educational institutions between 2010 and 2020. The number of almost all educational infrastructure institutions was a decrease. In particular, the number of secondary schools decreased by $25 \%$, vocational schools - by $27 \%$, higher educational institutions - by $29 \%$.

Unlike in Ukraine, the number of Polish vocational schools especially not changed between 2010 and 2020. According to the data in Table 1, vocational schools decreased by $8 \%$, i.e., in three times less than in Ukraine. At the same time the number of secondary schools decreased by $32 \%$, higher educational institutions - by 23\%. Meanwhile, compared to 2010, in 2020, the number of pre-school institutions had increased by $48 \%$ or by 4207 units.

The analysis of the data shows that the number of students in vocational schools and higher education institutions per 10 thousand of population was a significant decreased between 2010 and 2020 both in Ukraine and in Poland. Meanwhile, the number of students in higher education institutions per 10 thousand of population in Ukraine was decreased from 543 in 2010 to 332 in 2020 (i.e., less than 38\%). However, the situation is worse for the number of students in vocational schools per 10 thousand of population in Ukraine, which decreasedby $36 \%$, when in Poland this indicator increased by $8 \%$ or by 16 students per 10 thousand of population.

Chart 1 shows that Podkarpackie (209), Malopolskie (204) and Wielkopolskie (196) voivodships have more students in vocational schools per 10 thousand of populationin 2017. The number of vocational schools ranged from 399 in the voivodships to more than 300 per 10 inhabitants in Malopolskie (305), Wielkopolskie (323), Śląskie(395) and Mazowieckie(399) voivodships.

In Ukraine, the situation is worse in this aspect (see Chart 2). In 2017, the number of students in vocational schools ranged from 47 per 10 inhabitants in the Kyivs'ka (47), Zakarpats'ka (47), Chernihivs'ka (49), Kharkivs'ka (51) and Odes'ka (61) oblasts to more than 90 per 10 inhabitants in Sums'ka (90), L'vivs'ka (96) and Rivens'ka (99) oblasts, i.e., twice as many as in Poland.

The analysis of the correlation of variables of educational infrastructure in Poland allows for the elimination of the following indicators from further analysis:

- El. Number of pre-school institutions (correlated to the degree of excessive variables E 3 . Number of secondary schools, E 6 . Number of vocational schools and E 8. Number of higher education institutions); 
- E 3. Number of secondary schools (correlated to the degree of excessive variables El.Number of pre-school institutions, E 6. Number of vocational schools and E 8. Number of higher education institutions);

- E 8. Number of higher education institutions (correlated to the degree of excessive variables El. Number of pre-school institutions, E 3. Number of secondary schools and $\mathrm{E} 6$. Number of vocational schools).

Similarly, the analysis of the correlation of variables of educational infrastructure development in Ukraine allows for the elimination of the following indicators from further analysis:

- E 1. Number of pre-school institutions (correlated to the degree of excessive variable E 3. Number of secondary schools);

- E 8. Number of higher education institutions (correlated to the degree of excessive variables E 6. Number of vocational schools and E 9. Number of students in higher education institutions per 10 thousand of population).

Finally, after distribution of selected variables into stimulants or destimulants and normalization of variables by the standardization method, the synthetic indexof educational infrastructure development by Julian Perkal's method was calculated. The values of the synthetic index, rank, and group of each Polish voivodship are presented in Table 2, while the spatial differentiation of the educational infrastructure development is presented in Chart 3.The highest value of the synthetic index characterizes the region with the highest level of educational infrastructure development, the lowest value - the region with the lowest level.

For that reason, four groups were identified:

- group A - region-leaders, in which there is the highest level of educational infrastructure development;

- group B - leading regions, in which there is a high level of educational infrastructure development;

- group $\mathrm{C}$ - peripheral regions, in which there is an average level of educational infrastructure development;

- group D - regions-outsiders, in which there is a low level of educational infrastructure development.

Subsequently, the classification of Polish regions according to the value of Perkal's index shows that in 2017 the leader in the ranking of educational infrastructure development was Malopolskie voivodship, while last place was occupied Dolnoslaskie voivodship (see Chart 3).

At the other end of the scale, group A, with the highest level of educational infrastructure development was composed of the following voivodships: Malopolskie (0.9115) and Wielkopolskie (0.8072). A slightly less favourable situation was registered in voivodships belonging to group B, with a high level of educational infrastructure development, including Slaskie, Podkarpackie, Mazowieckie, and Lubelskie. Group $\mathrm{C}$ was the biggest, which included nine voivodships with a medium level of educational infrastructure development. The weakest voivodship is in group $\mathrm{D}$, and include Dolnoslaskie. 
The values of the synthetic index of educational infrastructure development, rank, and group of each Ukrainian oblasts are presented in Table 3, and the spatial distribution is in Chart 4.

Chart 4 demonstrates that group A, with a high level of educational infrastructure development, consists of only 3 leading regions, among which the highest level of the index was recorded in L'vivs'ka (1.1460), Rivens'ka (0.6210), and Vinnyts'ka (0.4061) oblasts.

Group B consists of 6 leading oblasts, which have a high level of educational infrastructure development: Ternopils'ka, Kharkivs'ka, Dnipropetrovs'ka, Khmel'nyts'ka, Odes'ka, and Volyns'ka. Due to the average level of development, eleven oblasts (the biggest one in Ukraine) were classified into group C. Group D consists of only 2 oblasts with a low level of educational infrastructure development: Chernihivs'ka and Kyivs'ka. Theseoblasts have the lowest values of indicators among all regions of Ukraine: number of students in vocational schools and in higher education institutions per 10 thousand of population.

\section{Conclusion}

The study provides an opportunity to draw the following conclusions that the condition and development of educational infrastructure in Ukrainian regions cannot be considered satisfactory, especially with regard to vocational and higher education. There was a decrease in the number of almost all educational infrastructure institutions.

The dynamics of the number of students in vocational schools and higher education institutions in Ukraine reflects, first, the demographic trends that have taken place and are taking place in the country, as well as society's attitude to vocational and higher education.

Moreover, the steady downward trend in the number of Ukrainian students during 2010-2020 is due to a reduction in the number of people of the appropriate age, as well as an annual increase in the number of students going abroad to study. These trends do not create conditions for the comprehensive development of personality and the formation of quality human potential.

Important to note, that the coronavirus pandemic was reshaping education infrastructure. Educational institutions and teachers across the world's educational systems had to transfer their work from classrooms and lecture halls to digital platforms (Teräs et al., 2020, p. 865).

According to this, the inevitable way of development in education infrastructure in the future is digitalization. Digitalization is not only to quality improvement, innovation, creativity and students' autonomy, but also to educational access and equity. But the pandemic has brought an accelerated digitalization in terms of rising inequality and exclusion.

The main directions of modernization of the educational infrastructure in the regions of Ukraine should be: 
- creating new and improving the accessibility and quality of existing educational infrastructure facilities;

- support for the development of competences and skills development of employees engaged in educational infrastructure;

- improvement of the educational infrastructure financing system;

- developing non-formal education, online learning and the system of lifelong learning.

Thus, in the conditions of innovative transformations the determinants of the impact of the educational component of the region's social infrastructure on human development should be carried out by increasing the level of compliance of educational services with labor market demands, activating participation of local communities in developing education, promoting self-education and lifelong learning.

\section{References}

Flora, C.B., \& Flora, J.L. (1993). Entrepreneurial social infrastructure: a necessary ingredient. The Annals of the American Academy of Political and Social Science, 529(1), 48-58.

Flora, J.L. (1998). Social capital and communities of place. Rural Sociology, 63(4), 481-506. https://doi.org/10.1111/j.1549-0831.1998.tb00689.x.

Kupiec, L., Gołębiowska, A., \& Wyszkowska, D. (2004). Gospodarka przestrzenna: infrastruktura spoteczna, 6. Uniwersytet w Białymstoku.

Revko, A. (2017). Problemy i infrastruktura społeczna na rynku pracy Ukrainy. Rynek Pracy, 4(163), 30-36.

State Statistics Service of Ukraine. (2021). Retrieved 19.09.2021 from http:// www.ukrstat.gov.ua.

Statistic Poland. (2021). Local data bank. Retrieved 19.09.2021 from https:// bdl.stat.gov.pl/BDL/start.

Teräs, M., Suoranta, J., Teräs, H., \& Curcher, M. (2020). Post-Covid-19 education and education technology 'solutionism': a seller's market. Postdigital Science and Education, 2(3), 863-878. https://doi.org/10.1007/ s42438-020-00164-x.

Witkowski, K., \& Starościc, D. (2008). System infrastruktury społecznej w gminie. Studia Lubuskie, 6, 1-18.

Wojnowski, J. (Ed.). (2002). Wielka Encyklopedia PWN, 12. PWN.

\section{Acknowledgements}

Author contributions: author has given an approval to the final version of the article.

Funding: this research was funded by the author's own sources.

Note: the results of this study were presented at 9th Scientific Conference: Contemporary Economic Problems 'Thirty years of transformation' (September, 16, 2020, online, Poland). 


\section{Appendix}

Table 1.

Dynamics of educational infrastructure in Poland and Ukraine, 2005-2020

\begin{tabular}{|c|c|c|c|c|c|c|c|}
\hline Indicator & 2010 & 2015 & 2016 & 2017 & 2018 & 2019 & 2020 \\
\hline \multicolumn{8}{|c|}{ Poland } \\
\hline number of pre-school institutions, units & 8704 & 11124 & 11520 & 11882 & 12146 & 12535 & 12911 \\
\hline number of secondary schools, units & 26415 & 25154 & 25135 & 25041 & 20229 & 19813 & 17961 \\
\hline $\begin{array}{l}\text { number of students in secondary schools per } 10 \\
\text { thousand of population, person }\end{array}$ & 1122 & 1072 & 1102 & 1043 & 1043 & 1041 & 996 \\
\hline number of vocational schools, units & 3865 & 3669 & 3592 & 3568 & 3394 & 3457 & 3557 \\
\hline $\begin{array}{l}\text { number of students in vocational schools per } 10 \\
\text { thousand of population, person }\end{array}$ & 204 & 182 & 178 & 175 & 171 & 170 & 220 \\
\hline number of higher education institutions, units & 453 & 415 & 390 & 397 & 392 & 353 & 348 \\
\hline $\begin{array}{l}\text { number of students in higher education institu- } \\
\text { tions per } 10 \text { thousand of population, person }\end{array}$ & 472 & 365 & 351 & 336 & 320 & 313 & 317 \\
\hline \multicolumn{8}{|c|}{ Ukraine } \\
\hline number of pre-school institutions, units & 14935 & 14813 & 14949 & 14907 & 14898 & 14763 & 15335 \\
\hline number of secondary schools, units & 20300 & 17337 & 16858 & 16180 & 16200 & 15500 & 15200 \\
\hline $\begin{array}{l}\text { number of students in secondary schools per } 10 \\
\text { thousand of population, person }\end{array}$ & 892 & 883 & 901 & 925 & 958 & 987 & 1012 \\
\hline number of vocational schools, units & 976 & 798 & 787 & 756 & 736 & 723 & 711 \\
\hline $\begin{array}{l}\text { number of students in vocational schools per } 10 \\
\text { thousand of population, person }\end{array}$ & 91 & 71 & 67 & 63 & 60 & 58 & 58 \\
\hline number of higher education institutions, units & 854 & 659 & 657 & 661 & 652 & 619 & 605 \\
\hline $\begin{array}{l}\text { number of students in higher education institu- } \\
\text { tions per } 10 \text { thousand of population, person }\end{array}$ & 543 & 375 & 372 & 363 & 361 & 343 & 332 \\
\hline
\end{tabular}

Source: Own preparation based on State Statistics Service of Ukraine (2021), Statistic Poland (2021).

Table 2.

Ranking of Polish regions according to the level of educational infrastructure development in 2017

\begin{tabular}{lccc}
\hline \multicolumn{1}{c}{ Region name } & Rank & Perkal's index & Group \\
\hline Malopolskie & 0.9115 & 1 & $\mathrm{~A}$ \\
Wielkopolskie & 0.8072 & 2 & $\mathrm{~A}$ \\
Slaskie & 0.2580 & 3 & $\mathrm{~B}$ \\
Podkarpackie & 0.2339 & 4 & $\mathrm{~B}$ \\
Mazowieckie & 0.1276 & 5 & $\mathrm{~B}$ \\
Lubelskie & 0.0640 & 6 & $\mathrm{~B}$ \\
Lubuskie & -0.0409 & 7 & $\mathrm{C}$ \\
Pomorskie & -0.0815 & 8 & $\mathrm{C}$ \\
Kujawsko-pomorskie & -0.1223 & 9 & $\mathrm{C}$ \\
Warminsko-mazurskie & -0.1441 & 10 & $\mathrm{C}$ \\
Opolskie & -0.1772 & 11 & $\mathrm{C}$ \\
Lodzkie & -0.2471 & 12 & $\mathrm{C}$ \\
Swietokrzyskie & -0.2474 & 13 & $\mathrm{C}$ \\
Zachodniopomorskie & -0.3137 & 14 & $\mathrm{C}$
\end{tabular}




\begin{tabular}{lccc}
\hline \multicolumn{1}{c}{ Region name } & Rank & Perkal's index & Group \\
\hline Podlaskie & -0.3247 & 15 & $\mathrm{C}$ \\
Dolnoslaskie & -0.7033 & 16 & $\mathrm{D}$ \\
\hline
\end{tabular}

Source: Own preparation based on Statistic Poland (2021).

Table 3.

Ranking of Ukrainian regions according to the level of educational infrastructure development in 2017

\begin{tabular}{lccc}
\hline \multicolumn{1}{c}{ Region name } & Rank & Perkal's index & Group \\
\hline L'vivs'ka & 1.1460 & 1 & $\mathrm{~A}$ \\
Rivens'ka & 0.6210 & 2 & $\mathrm{~A}$ \\
Vinnyts'ka & 0.4061 & 3 & $\mathrm{~A}$ \\
Ternopils'ka & 0.3717 & 4 & $\mathrm{~B}$ \\
Kharkivs'ka & 0.2680 & 5 & $\mathrm{~B}$ \\
Dnipropetrovs'ka & 0.1388 & 6 & $\mathrm{~B}$ \\
Khmel'nyts'ka & 0.1284 & 7 & $\mathrm{~B}$ \\
Odes'ka & 0.0427 & 8 & $\mathrm{~B}$ \\
Volyns'ka & 0.0109 & 9 & $\mathrm{~B}$ \\
Ivano-Frankivs'ka & -0.0142 & 10 & $\mathrm{C}$ \\
Sums'ka & -0.0285 & 11 & $\mathrm{C}$ \\
Zhytomyrs'ka & -0.0457 & 12 & $\mathrm{C}$ \\
Zakarpats'ka & -0.0900 & 13 & $\mathrm{C}$ \\
Cherkas'ka & -0.1108 & 14 & $\mathrm{C}$ \\
Khersons'ka & -0.1984 & 15 & $\mathrm{C}$ \\
Mykolayivs'ka & -0.2015 & 16 & $\mathrm{C}$ \\
Kirovograds'ka & -0.2317 & 17 & $\mathrm{C}$ \\
Poltavs'ka & -0.2909 & 18 & $\mathrm{C}$ \\
Zaporiz'ka & -0.3304 & 19 & $\mathrm{C}$ \\
Chernivets'ka & -0.3376 & 20 & $\mathrm{C}$ \\
Chernihivs'ka & -0.6218 & 21 & $\mathrm{D}$ \\
Kyivs'ka & -0.6320 & 22 & $\mathrm{D}$ \\
\hline
\end{tabular}

Source: Own preparation based on State Statistics Service of Ukraine (2021). 
Chart 1.

Number of students and vocational schools in Poland in 2017

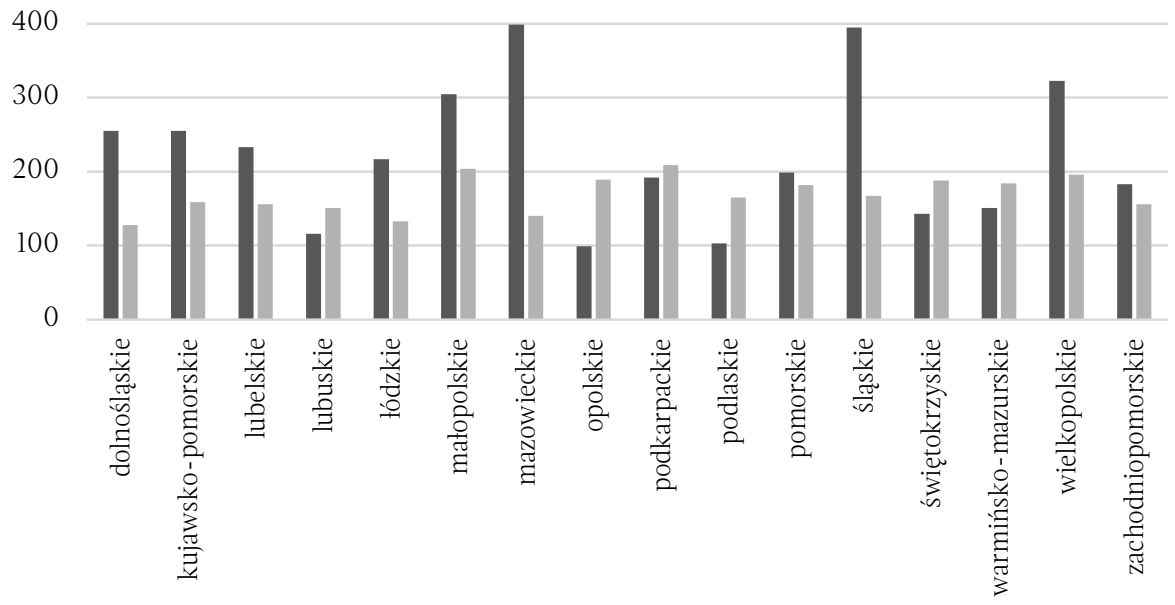

number of vocational schools (units)

number of syudents in vocational schools per 10 thousand of population (person)

Source: Own preparation based on Statistic Poland (2021).

Chart 2.

Number of students and vocational schools in Ukraine in 2017

100

80

60

40

20

0

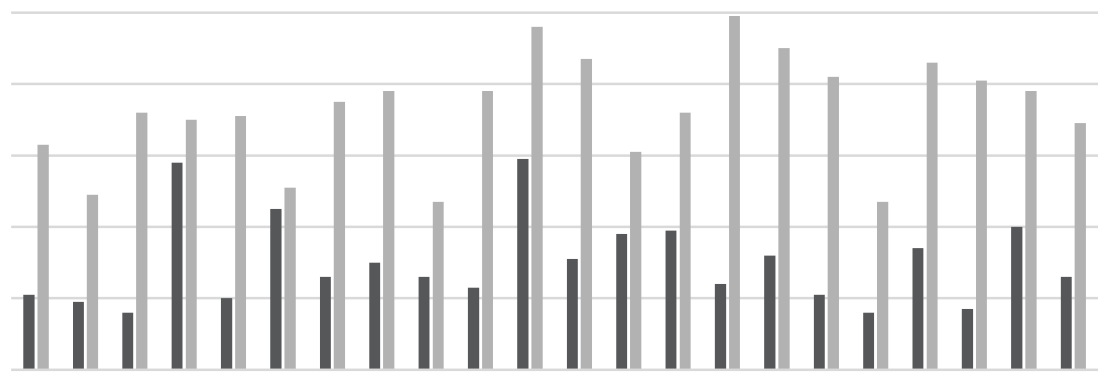

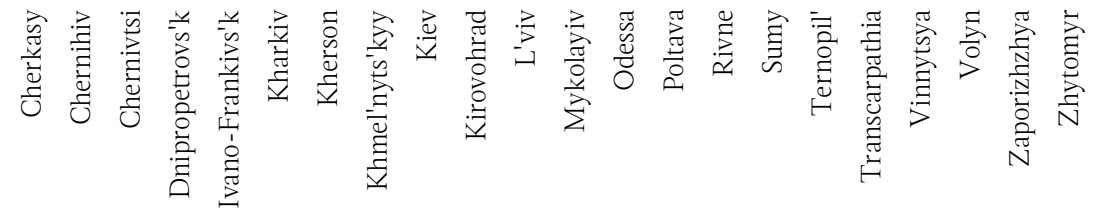

- number of vocational schools (units)

number of syudents in vocational schools per 10 thousand of population (person)

Source: Own preparation based on State Statistics Service of Ukraine (2021). 
Chart 3.

Map of regional differentiation of the index of educational infrastructure development in Poland in 2017

1.2

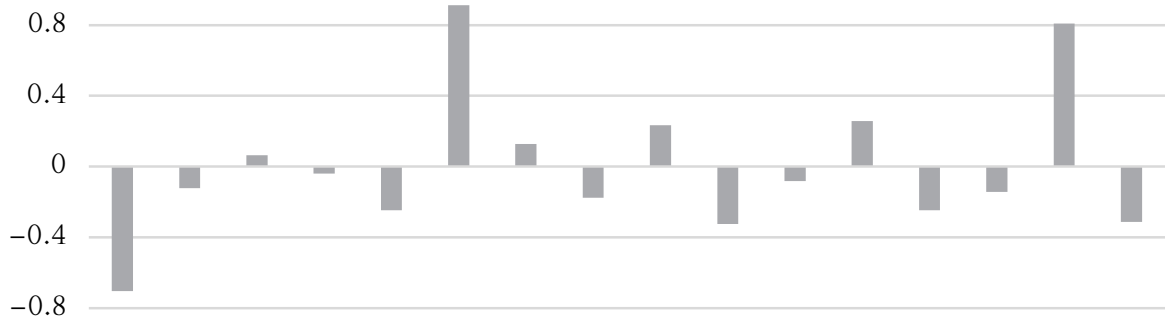

$-0.8$

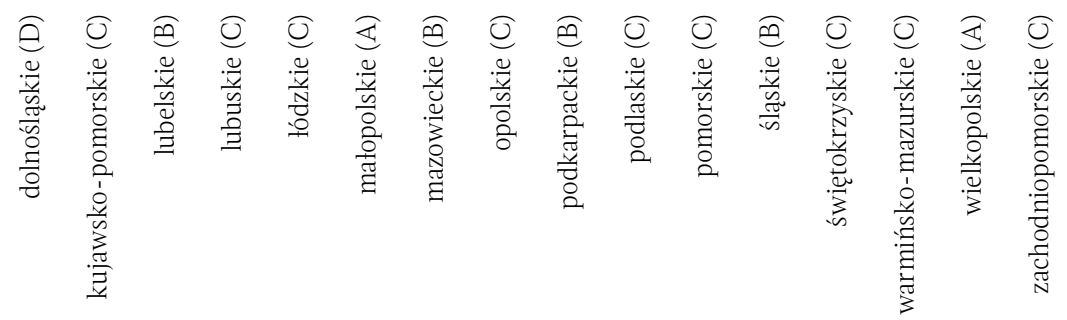

Source: Own preparation based on Statistic Poland (2021).

Chart 4.

Map of regional differentiation of the index of educational infrastructure development in Ukraine in 2017

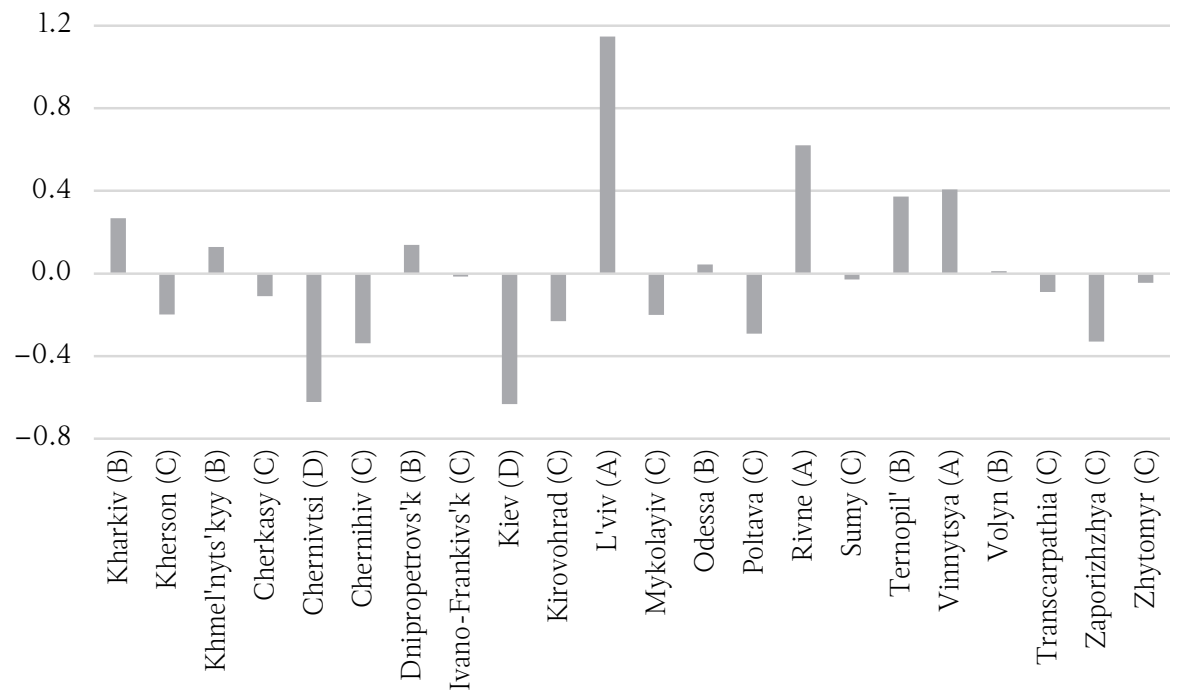

Source: Own preparation based on State Statistics Service of Ukraine (2021). 